\title{
The Association of the $B R A F-V 600 E$ Mutation with the Expression of the Molecular Markers in the Primary Tumor and Metastatic Tissue in Papillary Thyroid Cancer
}

\author{
Liudmila V. Spirina ${ }^{1,2 *}$, Svetlana Yu. Chizhevskaya ${ }^{3,4}$, Irina V. Kovaleva ${ }^{5,6}$, Irina \\ V. Kondakova ${ }^{7}$
}

\begin{abstract}
Objective: The aim of this study was investigation the AKT / mTOR signaling pathway components, transcriptional and growth factors, as well as steroid hormone receptors and nuclear factors Brn-3 $\alpha$ and TRIM16 expression in the tissue of the primary thyroid tumor and metastases, depending on the $B R A F-V 600 \mathrm{E}$ status. Material and Methods: The study was enrolled 20 patients with PTCs, who underwent surgical treatment. They were divided into negative $B R A F$ V600E status (12 people), positive $B R A F$-V600E status ( 8 patients). Mutation status was assessed in paired metastatic tissue samples. The molecular marker expression was determined by real-time PCR. The Real-time-PCR-BRAF-V600E reagent kit evaluated the $B R A F$-V600E mutation. Results: A decrease in the PDK kinase, PTEN, VHL mRNA level in primary cancers was noted, compared with metastases' tissue. An increase in AKT, GSK-3 $\beta$, mTOR, 70s 6 kinase was revealed in cancers with point mutation compared with the primary tumor without a mutation. Positive mutation status

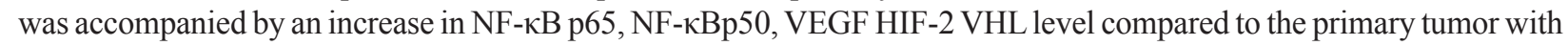
negative $B R A F-\mathrm{V} 600 \mathrm{E}$ status. In the metastases with the $B R A F-\mathrm{V} 600 \mathrm{E}$ point mutation, a decrease in the PDK kinase, HIF-1; VHL; TRIM16, and ER $\alpha$ expression was observed, compared to lymph node metastases (LNMs) without the mutation. The concordance in the BRAF-V600E tumor status and LNMs was observed only in $50 \%$ of patients. If the $B R A F$ gene status did not match PTCs and LNMs, an increase in the mTOR, NFkBp65, VHL, and ER $\alpha$ mRNA levels was found in the PTCs. In LNMs, there was an increase in the c-RAF PTEN NFkBp65 VHL expression compared to non-concordant ones. Conclusion: The heterogeneity in the primary tissue's expression profile and metastases was noted. The BRAF-V600E mutation can affect the molecular characteristics both in the primary cancers and metastases. The discrepancy between the mutant status and the molecular factors expression variability in the primary tumor and LNMs determines its progression.
\end{abstract}

Keywords: Thyroid cancer; $B R A F-V 600$ E, primary tumor; metastases; molecular factors

Asian Pac J Cancer Prev, 22 (7), 2017-2024

\section{Introduction}

Thyroid cancer is a dynamic disease; during disease, cancers generally become more heterogeneous (Albini et al., 2012). Heterogeneity provides the fuel for resistance; therefore, an accurate assessment of tumor heterogeneity is essential for developing effective therapies. Thyroid cancer is a heterogeneous group of diseases. The current molecular markers that have received the most attention in thyroid cancer include $B R A F$, point mutations, and PAX8/PPARG and RET/PTC rearrangements (Bhagirath et al., 2019).

Despite the rapidly developing field of molecular markers, several limitations exist. Thyroid cancer behavior is defined by the effects of the initiating oncogene and secondary events in tumor cells and the tumor microenvironment that is genetic and epigenetic (Ge et al., 2020). The long-observed age-associated mortality risk in PTC is dependent on $B R A F$ status; age is an intense, continuous, and independent mortality risk factor in patients with $B R A F-\mathrm{V} 600 \mathrm{E}$ mutation but not in patients with wild-type $B R A F$. These results question

\footnotetext{
${ }^{1}$ Laboratory of Tumor Biochemistry, Cancer Research Institute, Tomsk National Research Medical Center, Russian Academy of Medical Sciences, Russian Federation. ${ }^{2}$ Division of Biochemistry and Molecular, Russian Federation. ${ }^{3}$ Division of Head and Neck Cancers, Cancer Research Institute, Tomsk National Research Medical Center, Russian Academy of Medical Sciences, Russian Federation. ${ }^{4}$ Division of Oncology, Siberian State Medical University, Russian Federation. ${ }^{5}$ Siberian State Medical University, Tomsk, Russian Federation. ${ }^{6}$ Cancer Research Institute, Siberian State Medical University, Tomsk, Russian Federation. ${ }^{7}$ Cancer Research Institute, Tomsk National Research Medical Center, Russian Academy of Sciences, Tomsk, Russian Federation. *For Correspondence: spirinalvl@mail.ru
} 
the conventional general use of patient age as a high-risk factor in PTC and call for differentiation between patients with $B R A F-\mathrm{V} 600 \mathrm{E}$ and wild-type $B R A F$ when applying age to risk stratification and management of PTC (Califano et al., 2018).

The $B R A F-\mathrm{V} 600 \mathrm{E}$ point mutation is the most common genetic mutation detected in patients with papillary thyroid cancer (PTC) and occurs in approximately 45-60\% of patients (Califano et al., 2018; Chen et al., 2018). Over the past several years, there has been intense focus on identifying molecular markers to predict the aggressiveness of thyroid cancers better and define therapeutic targets. It is known that the c-RAF protein's mutation with the formation of the b-RAF oncoprotein has a significant effect on cancer progression. Patients with PTC have biological markers associated with this somatic mutation. According to the data presented in previous work, the $B R A F-\mathrm{V} 600 \mathrm{E}$ mutation is accompanied by an increase in the growth and transcription factors mRNA level with a reduction in the AKT/mTOR signaling pathway activity (Chen et al., 2020).

The presented molecular parameters are responsible for angiogenesis, the immune response initiation, and apoptosis blockage resulting in abnormal cell growth with the potential to invade or spread to other parts of the body (Albini et al., 2012). Angiogenesis also plays a crucial role in spreading cancer cells and colonization at the body's distant locations and metastasis formation (Dagogo-Jack et al., 2018). It is regulated by hypoxia-inducible factors and, followed by the elevated VEGF, is responsible for the vessel formation. The von Hippel-Lindau (VHL) tumor suppressor gene's significance in the PTC progression seems to be essential (Gawin et al., 2019). The lower VHL expression in cancers is a sign of the aggressive tumor's behavior and neoangiogenesis initiation (Halon et al., 2012). Angiogenesis is a key event related to tumor progression in PTC (Jena et al., 2019).

Recently, the system's importance for controlling hormone receptor expression mediated by nuclear peptides became evident in PTC. The transcription factor Brn- $3 \alpha$ can affect androgen and estrogen receptors (Kurtulmus et al., 2016; Lodewijk ey al., 2017).

It is observed the participation of Tripartite motif 16 (TRIM16) protein in the pathogenesis of hormonedependent tumors due to its "anti-estrogenic effect" (Tan et al., 2017). The effect of TRIM16 on epithelialmesenchymal transition (EMT) and metastasis in cancer cells has a clinical significance in cancer progression (Melo et al., 2017). The PTC is characterized by an increased level ER $\beta$, AR mRNA, which is related to the peculiarities in the nuclear factors Brn-3a, TRIM16 level (Magri et al., 2012). Nuclear factors Brn-3 $\alpha$ and TRIM16 modulating expression of steroid hormones play an essential role in developing thyroid tumors. It was found TRIM16 mRNA level was associated with the expression of ER $\beta$, which seems to be mediated by its "anti-estrogen effect" (Spirina et al., 2018; Jena et al., 2019).

Little is known about the frequency of critical mutations in thyroid cancer metastases and their relationship with the primary tumor genotype. The distant metastasis in PTC is associated with an adverse disease outcome. It is widely known that an unfavorable outcome characterizes the development of metastases. In half of the cases, lymph node metastases (LNMs) were found in patients undergoing surgical thyroid resection ( $\mathrm{Lu}$ et al, 2015; Parameswaran R, et al, 2017).

$B R A F, \mathrm{RAS}$, and TERT mutations are highly prevalent in metastatic differentiated thyroid cancer and are concordant between primary and metastatic cancers (Sadow et al., 2010). The value of selected mutations for tumor risk stratification and assessment of patients' prognosis was affirmed. To date, there are ideas about its importance in the aggressive tumor potential in oncogenesis, cancer behavior, and patient's outcome (Spirina et al., 2018; Spirina et al., 2019). The high concordance for all the genes was found comparing the genotype of primary tumors with lymph node metastasis (LNMs). On the other hand, distant metastases show enrichment in TERTp mutations and decrease $B R A F$ mutations (Sadow et al., 2010).

Currently, the heterogeneity of the $B R A F-\mathrm{V} 600 \mathrm{E}$ status of the primary tumor and metastases, concordance, and tissue coincidence are widely studied. It is noted that the coincidence of the gene status is observed in the majority of patients (95.2\%) (Sohn et al., 2016). Only 4.8\% had a heterogeneous status for this mutation, which was observed in patients with a disease's recurrent course. In turn, there is information about the protective effect of the $B R A F-\mathrm{V} 600 \mathrm{E}$ mutation and a decrease in the likelihood of lung damage in papillary thyroid cancer (Shen et al., 2018). Despite the previous data of unfavorable prognosis in mutant b-RAF protein turnover, it is obtained to be a sign of response to radioiodine therapy in PTC (Califano et al., 2018). In common, Chen found (2020) no relationship between the BRAF-V600E mutation in LNM and its invasive characteristics in PTC (Chen et al., 2020).

Consequently, a tumor's biological behavior is mediated by a complex of molecular markers, which include the AKT/mTOR signaling pathway components, transcription and growth factors, and steroid hormone receptors and nuclear factors associated with them. The study aimed to study the AKT / mTOR signaling pathway components, transcriptional and growth factors, as well as steroid hormone receptors and nuclear factors Brn-3 $\alpha$ and TRIM16 expression in the tissue of the primary thyroid tumor and metastases, depending on the $B R A F$ - V600E status.

\section{Material and Methods}

The study included 20 patients with PTC, T1-4N02M0 stages, who underwent surgical treatment in the Cancer Research Institute's clinics, Tomsk National Research Medical Center. Patients were divided into two groups: without the BRAF-V600E mutation, which included 12 people, and with its presence - 8 people. Mutation status was assessed in paired metastatic tissue samples. We revealed in 6 metastases positive mutation status, and 14 ones had a negative status.

The study's material was samples of the tumor, non-transformed tissue of the thyroid gland, located at least $1 \mathrm{~cm}$ from the tumor's border, and tissue of affected 
and unaffected lymph nodes were frozen after collection and stored at $\mathrm{t}-80^{\circ} \mathrm{C}$. The Local Committee approved the study for Medical Ethics, and all patients provided written informed consent. All procedures involving patients were carried out by the Declaration of Helsinki's Declaration on Human Rights (1964). All patients signed informed consent to participate in the study.

\section{Isolation of DNA}

DNA was isolated using the FFPET DNA - Extraction Kit (Biolink, Russia). Its concentration was assessed on a NanoDrop-2000 spectrophotometer (Thermo Scientific, USA). The resulting DNA was used for realtime PCR. Determination of the BRAF-V600E mutation. The $B R A F-\mathrm{V} 600 \mathrm{E}$ mutation was determined using the Real-time-PCR-BRAF-V600E reagent kit, designed to detect GTG GGG's point mutation in codon 600 of the $B R A F$ gene. The analysis is carried out by allele-specific real-time PCR.

\section{RNA extraction}

The postoperative tumor samples were incubated in RNAlater solution (Ambion, USA) for 24-hours at $+4{ }^{\circ} \mathrm{C}$ and then stored at $-80^{\circ} \mathrm{C}$. Total RNA was extracted using RNeasy Mini Kit (Qiagen).

\section{$R T-q P C R$}

PCR was conducted in $25 \mu$ reaction volumes containing $12.5 \mu \mathrm{l}$ BioMaster HS-qPCR SYBR Blue (2X) ("Biolabmix" Russia) and 300 nano $\mathrm{M}$ of each primer. Primers were selected using the Vector NTI Advance 11.5 software and the NCBI database (HTTP: //www.ncbi.nlm. nih.gov/nuccore) (Table 1).

A pre-incubation at $95^{\circ} \mathrm{C}$ for $10 \mathrm{~min}$ was to activate the Hot Start DNA polymerase and denature DNA. It was followed by 45 amplification cycles of $95^{\circ} \mathrm{C}$ denaturations at $95^{\circ} \mathrm{C}$ for $10 \mathrm{sec}, 60^{\circ} \mathrm{C}$ annealings at $60^{\circ} \mathrm{C}$ for $20 \mathrm{sec}$ (iCycler $\mathrm{iQ}^{\mathrm{TM}}$, BioRad).

The housekeeping gene of the GAPDH (glyceraldehyde-3-phosphate dehydrogenase) enzyme was used as a reference gene, and the expression level of each target gene was normalized to the expression of GAPDH. The fold changes were calculated by the $\Delta \Delta \mathrm{Ct}$ method (the total $\Delta \Delta \mathrm{Ct}=$ fold of cancerous/normal tissue gene level), using normal tissue. A ratio of specific mRNA/GADPH (GADPH as a respective control) amplification was then calculated.

The statistical analysis was performed using the Statistica 8.0 software package. Verification of normality was performed using the Kolmogorov-Smirnov test. The results of the determination of gene expression are presented as Me (Q1; Q3). The Mann-Whitney test assessed the significance of differences. Differences were considered significant at $p<0.05$. The significance of differences in the frequencies of qualitative traits was evaluated using the $\chi^{2}$ criterion with the Yates correction.

\section{Results}

Molecular markers play a significant role in the oncogenesis and PTC spreading. Table 2 presents data
The BRAF-V600E Mutation and Papillary Thyroid Cancer

on the AKT/mTOR signaling pathway components in the primary tumor and metastases. A decrease in the PDK kinase and PTEN phosphatase mRNA level was noted by 2.23 and 5.6 times in the metastases, respectively, compared with the primary tumor tissues. Simultaneously, the NF- $\kappa \mathrm{B}$ p50 and VHL expression decreased by 32.4 and 14.8 times, respectively, in the metastases compared with the primary papillary tumors.

The detection of molecular alterations in thyroid carcinogenesis in the signaling pathways relates to some diagnostic, prognostic, and treatment issues. The clinical implications of $B R A F$ altered gene and molecules impact the change in AKT/mTOR signaling pathway components, transcription and growth factors, hormone receptors, and nuclear factors Brn-3 $\alpha$, TRIM16 (Table 3). Mutation status in the primary tumor led to an increase in the AKT, GSK-3 $\beta$, mTOR, the 70 s 6 kinase expression in 19.9; 47.1; 164.3 ; 101.6 times, respectively with the primary tumor without a mutation. NF- $\kappa$ Bp $65, \mathrm{NF}-\kappa B p 50, \mathrm{VEGF}$, HIF2; VHL elevated mRNA level by 10.6 ; 13.5 ; 240.6; 11.5; 368.5 times found in tumors with mutation, respectively, compared to the primary tumor with the wild variant of the $B R A F$ gene.

On the contrary, positive $B R A F-\mathrm{V} 600 \mathrm{E}$ status in the LNMs was associated with decreased molecular markers' expression. PDK kinase; HIF-1; VHL; transcription factor TRIM16, and ER $\alpha$ mRNA level in metastases with a $B R A F-\mathrm{V} 600 \mathrm{E}$ mutation was reduced in $2.1 ; 27,42.33$; $4.0 ; 42.4$ and 8.0 times, respectively, compared to LNMs without this mutation.

$B R A F$ mutations are associated with the abnormal regulation of microRNA, constitute the most frequent molecular alterations identified in PTC, determining cancer's biological characteristics and the disease's outcome. The heterogeneity in the primary tumor and LNMs is widely known, followed by the molecular and genetic markers' change. The study revealed that the primary tumor mutation was observed in $40 \%$ of patients, while only $10 \%$ of patients retained it in the metastatic tissues (Table 4). Among patients with a negative status for the $B R A F-\mathrm{V} 600 \mathrm{E}$ mutation $(60 \%$ of the total number of patients), the same metastatic status was observed in $20 \%$ of patients. In $40 \%$ of patients, the mutation appeared in the LNMs.

Consequently, concordance in BRAF-V600E tumor status and metastases was observed only in $50 \%$ of patients: $10 \%$ for a positive status in the primary tumor and metastases and $40 \%$ for a negative status. The majority of patients with a positive tumor status in metastases did not have a mutation ( $30 \%)$. Only in $20 \%$ of patients from $60 \%$, we found the $B R A F-\mathrm{V} 600 \mathrm{E}$ point mutation in the LNMs in patients with a $B R A F-V 600 \mathrm{E}$ negative status in the primary tumors.

The molecular and genetic markers overlap are currently intensively studied. In the absence of concordance, an increase in the studied molecular markers expression was indicated in the primary tumor and metastases. If the $B R A F$ gene status did not match in the cancers and metastases, an increase in the level of mTOR mRNA, NFkBp65; VHL; ER $\alpha$ was observed in $32.8 ; 67.3 ; 56.0 ; 1.5$ times. In the LNMs with non-identical $B R A F$ gene status in 
Table 1. Sequences of primers

\begin{tabular}{|c|c|c|}
\hline Gene & Amplicon & Sequence \\
\hline $\begin{array}{l}\text { CAIX } \\
\text { NM_001216.2 }\end{array}$ & $217 \mathrm{bp}$ & $\begin{array}{l}\text { F 5'-GTTGCTGTCTCGCTTGGAA-3' } \\
\text { R 5'-CAGGGTGTCAGAGAGGGTGT-3' }\end{array}$ \\
\hline $\begin{array}{l}H I F-1 \alpha \\
\text { NM_001243084.1 }\end{array}$ & $188 \mathrm{bp}$ & $\begin{array}{l}\text { F 5'- CAAGAACCTACTGCTAATGCCA-3' } \\
\text { R 5'- TTTGGTGAGGCTGTCCGA-3' }\end{array}$ \\
\hline $\begin{array}{l}\text { EPAS1 } \\
\text { NM_001430.4 }\end{array}$ & $265 \mathrm{bp}$ & $\begin{array}{l}\text { F 5'- TGGAGTATGAAGAGCAAGCCT-3' } \\
\text { R 5'-GGGAACCTGCTCTTGCTGT-3' }\end{array}$ \\
\hline $\begin{array}{l}\text { NFKB1 } \\
\text { NM_001165412.1 }\end{array}$ & 144 bp & $\begin{array}{l}\text { F 5'-CGTGTAAACCAAAGCCCTAAA-3' } \\
\text { R 5'-AACCAAGAAAGGAAGCCAAGT-3' }\end{array}$ \\
\hline $\begin{array}{l}\text { RELA } \\
\text { NM_001145138.1 }\end{array}$ & $271 \mathrm{bp}$ & $\begin{array}{l}\text { F 5'-GGAGCACAGATACCACCAAGA-3' } \\
\text { R 5'-GGGTTGTTGTTGGTCTGGAT-3' }\end{array}$ \\
\hline $\begin{array}{l}\text { PTEN } \\
\text { NM_001304717.2 }\end{array}$ & $136 \mathrm{bp}$ & $\begin{array}{l}\text { F 5'-GGGAATGGAGGGAATGCT-3' } \\
\text { R 5'-CGCAAACAACAAGCAGTGA-3' }\end{array}$ \\
\hline $\begin{array}{l}\text { VEGFA } \\
\text { NM_001025366.2 }\end{array}$ & $316 \mathrm{bp}$ & $\begin{array}{l}\text { F 5'-AGGGCAGAATCATCACGAA-3' } \\
\text { R 5'-TCTTGCTCTATCTTTCTTTGGTCT-3' }\end{array}$ \\
\hline $\begin{array}{l}\text { KDR } \\
\text { NM_002253.2 }\end{array}$ & $306 \mathrm{bp}$ & $\begin{array}{l}\text { F 5'-AACACAGCAGGAATCAGTCA-3' } \\
\text { R 5'-GTGGTGTCTGTGTCATCGGA-3' }\end{array}$ \\
\hline $\begin{array}{l}4 E B P 1 \\
\text { NM_004095.3 }\end{array}$ & $244 \mathrm{bp}$ & $\begin{array}{l}\text { F 5'- CAGCCCTTTCTCCCTCACT -3' } \\
\text { R 5'- TTCCCAAGCACATCAACCT -3' }\end{array}$ \\
\hline $\begin{array}{l}\text { AKT1 } \\
\text { NM_001014431.1 }\end{array}$ & $181 \mathrm{bp}$ & $\begin{array}{l}\text { F 5'- CGAGGACGCCAAGGAGA -3' } \\
\text { R 5'- GTCATCTTGGTCAGGTGGTGT -3' }\end{array}$ \\
\hline $\begin{array}{l}C-R A F \\
\text { NM_002880.3 }\end{array}$ & $152 \mathrm{bp}$ & $\begin{array}{l}\text { F 5'- TGGTGTGTCCTGCTCCCT -3' } \\
\text { R 5'- ACTGCCTGCTACCTTACTTCCT -3' }\end{array}$ \\
\hline $\begin{array}{l}G S K 3 b \\
\text { NM_001146156.1 }\end{array}$ & $267 \mathrm{bp}$ & $\begin{array}{l}\text { F 5'- AGACAAGGACGGCAGCAA -3' } \\
\text { R 5'-CTGGAGTAGAAGAAATAACGCAAT-3' }\end{array}$ \\
\hline $\begin{array}{l}\text { 70S kinase alpha } \\
\text { NM_001272042.1 }\end{array}$ & $244 \mathrm{bp}$ & $\begin{array}{l}\text { F 5'- CAGCACAGCAAATCCTCAGA -3' } \\
\text { R 5'- ACACATCTCCCTCTCCACCTT -3' }\end{array}$ \\
\hline $\begin{array}{l}m-T O R \\
\text { NM_004958.3 }\end{array}$ & $160 \mathrm{bp}$ & $\begin{array}{l}\text { F 5'- CCAAAGGCAACAAGCGAT-3' } \\
\text { R 5'- TTCACCAAACCGTCTCCAA -3' }\end{array}$ \\
\hline $\begin{array}{l}\text { PDK1 } \\
\text { NM_001278549.1 }\end{array}$ & $187 \mathrm{bp}$ & $\begin{array}{l}\text { F 5'- TCACCAGGACAGCCAATACA -3' } \\
\text { R 5'- CTCCTCGGTCACTCATCTTCA -3' }\end{array}$ \\
\hline $\begin{array}{l}\text { POU } 4 F 1 \\
\text { NM_006237 }\end{array}$ & 294 bp & $\begin{array}{l}\text { F 5'- CACGCTCTCGCACAACAA-3' } \\
\text { R 5'- ATCCGCTTCTGCTTCTGTCT-3' }\end{array}$ \\
\hline $\begin{array}{l}A R \\
\text { NM_000044 }\end{array}$ & $190 \mathrm{bp}$ & $\begin{array}{l}\text { F 5'- GAGGGACAGCAGGCAGA-3' } \\
\text { R 5'- GCTATCAGAACACACACACACACT-3' }\end{array}$ \\
\hline $\begin{array}{l}\text { ESR1 ER } \alpha \\
\text { NM_000125 }\end{array}$ & $386 \mathrm{bp}$ & $\begin{array}{l}\text { F 5'- TCCTGATGATTGGTCTCGTCT-3' } \\
\text { R 5'- GATGTGGGAGAGGATGAGGA-3' }\end{array}$ \\
\hline $\begin{array}{l}\text { ESR2 ERß } \\
\text { NM_001040275.1 }\end{array}$ & $243 \mathrm{bp}$ & $\begin{array}{l}\text { F 5'- GGTCCATCGCCAGTTATCAC-3' } \\
\text { R 5'- GCCTTACATCCTTCACACGA-3' }\end{array}$ \\
\hline $\begin{array}{l}\text { TRIM16 } \\
\text { NM_001348119 }\end{array}$ & $267 \mathrm{bp}$ & $\begin{array}{l}\text { F 5'- CAATGGAACGGGAAGGAG-3' } \\
\text { R 5'- GGACGGTGCTGGCTTCT-3' }\end{array}$ \\
\hline $\begin{array}{l}V H L \\
\text { NM_000551.3 }\end{array}$ & 339 bp & $\begin{array}{l}\text { F 5'- GGCAGGCGAATCTCTTGA-3' } \\
\text { R 5'- CTATTTCCTTTACTCAGCACCATT-3' }\end{array}$ \\
\hline $\begin{array}{l}\text { GAPDH } \\
\text { NM } 001256799.2\end{array}$ & $138 \mathrm{bp}$ & $\begin{array}{l}\text { F 5'- GGAAGTCAGGTGGAGCGA-3' } \\
\text { R 5'-GCAACAATATCCACTTTACCAGA-3' }\end{array}$ \\
\hline
\end{tabular}

Note: NM is the RNA sequence number in the NCBI Nucleotide Database (http://www.ncbi.nlm.nih.gov/nuccore); F, forward primer; $\mathrm{R}$, reverse primer. 
Table 2. Molecular Markers Expression in the Primary Tumor and Metastases in PTC

\begin{tabular}{|c|c|c|}
\hline Indicator, Relative Units & Primary tumor & Metastases \\
\hline \multicolumn{3}{|c|}{ AKT / mTOR signaling pathway components } \\
\hline PDK & $2,88(1,00 ; 147,36)$ & $1,26(0,00 ; 2,02)^{*}$ \\
\hline AKT & $1,21(0,38 ; 3,21)$ & $0,73(0,38 ; 1,81)$ \\
\hline c-RAF & $3,09(0,38 ; 64,00)$ & $0,31(0,05 ; 3,84)$ \\
\hline GSK-3 $\beta$ & $1,22(0,39 ; 24,60)$ & $3,81(0,78 ; 11,92)$ \\
\hline mTOR & $1,65(0,07 ; 16,44)$ & $2,15(0,50 ; 4,10)$ \\
\hline 70s 6 киназа & $1,19(0,38 ; 11,65)$ & $0,67(0,27 ; 2,00)$ \\
\hline 4EBP1 & $0,12(0,01 ; 0,74)$ & $2,28(0,00 ; 3,32)$ \\
\hline PTEN & $5,39(0,50 ; 14,39))$ & $0,96(0,02 ; 1,30)^{*}$ \\
\hline \multicolumn{3}{|c|}{ Transcription and growth factors } \\
\hline NFкBp65 & $27,58(0,76 ; 64,38)$ & $4,46(0,13 ; 56,00)$ \\
\hline NFкBp50 & $27,62(3,72 ; 89,33)$ & $0,85(0,35 ; 16,00)^{*}$ \\
\hline VEGFR2 & $0,44(0,06 ; 8,59)$ & $0,49(0,10 ; 7,26)$ \\
\hline VEGF & $0,69(0,13 ; 12,13)$ & $1,25(0,02 ; 12,13)$ \\
\hline CA9 & $2,13(0,50 ; 7,01)$ & $0,37(0,03 ; 8,57)$ \\
\hline HIF-2 & $1,13(0,43 ; 3,03))$ & $1,52(0,13 ; 27,62)$ \\
\hline HIF-1 & $5,35(0,50 ; 16,62)$ & $3,28(0,12 ; 13,72)$ \\
\hline VHL & $20,1((0,85 ; 154,0)$ & $1,36(0,09 ; 5,59)^{*}$ \\
\hline \multicolumn{3}{|l|}{ Hormone reception } \\
\hline TRIM16 & $0,13(0,01 ; 1,73)$ & $2,83(0,18 ; 7,63)$ \\
\hline Brn & $1,54(0,22 ; 21,56)$ & $5,53(0,38 ; 11,59)$ \\
\hline $\mathrm{AR}$ & $0,45(0,02 ; 11,49)$ & $0,54(0,02 ; 2,00)$ \\
\hline $\mathrm{ER} \alpha$ & $1,44(1,02 ; 18,10)$ & $1,52(1,00 ; 8,00)$ \\
\hline $\mathrm{ER} \beta$ & $1,09(0,76 ; 6,70)$ & $0,77(0,10 ; 1,96)$ \\
\hline
\end{tabular}

The BRAF-V600E Mutation and Papillary Thyroid Cancer

cancerous tissues, there was an increase in the c-RAF PTEN NFkBp65 VHL expression in 16.0; 13.3; 60.0; 36.9 times, respectively, compared to concordant tissues.

\section{Discussion}

Change in PTCs molecular profile followed by the overexpression transcription and growth factors is typical of papillary thyroid cancer (Spirina et al, 2019). The BRAF-V600E mutation is a significant unfavorable prognostic sign in the PTC progression, predicting the response to anti-cancer therapy and diseases' outcome (Stanley et al., 2012). A molecular profile determines the rate of the direction of processes in oncogenesis. Previous studies have shown its association with the transcription and growth factors overexpression (Spirina et al., 2018). Its relationship with the molecular markers expression profile in the primary tumor and the LNMs was noted. For a primary tumor in genetic alteration, we found molecular markers overexpression associated with aggressive tumor growth. On the contrary, for metastatic tissue, a decrease in the RNA level molecular markers and a change in the molecular profile characteristics were noted. The study revealed the contribution of the HIF-1 and VHL in aggressive PTC behavior. We showed VHL significance in PCT oncogenesis, resulting in the LNMs alteration and the angiogenesis switching on. Low VHL expression was associated with the angiogenesis initiation, accompanied by the transcription and growth factors increase (Stanojevic et al., 2014; Todorović et al., 2018).

Table 3. Molecular Markers Expression in the Pprimary Tumor, Metastases and the BRAF-V600E Status

\begin{tabular}{|c|c|c|c|c|}
\hline Indicator, Relative Unit & $\begin{array}{c}\text { Primary tumor } \\
\text { without mutation }\end{array}$ & $\begin{array}{l}\text { Primary tumor with BRAF-V600E } \\
\text { mutation }\end{array}$ & $\begin{array}{l}\text { Metastases without } \\
\text { mutation }\end{array}$ & $\begin{array}{c}\text { Metastases with BRAF-V600E } \\
\text { mutation }\end{array}$ \\
\hline \multicolumn{5}{|c|}{ AKT / mTOR signaling pathway components } \\
\hline PDK & $1.26(0.60 ; 2.24)$ & $195.68(104.37 ; 264.10)$ & $2.02(1.77 ; 113.71)$ & $1.00(0.01 ; 1.52)^{* *}$ \\
\hline $\mathrm{AKT}$ & $0.69(0.06 ; 0.74)$ & $13.78(2.97 ; 152.19) *$ & $0.78(0.68 ; 1.02)$ & $0.54(0.38 ; 15.96)$ \\
\hline c-RAF & $0.89(0.25 ; 64.0)$ & $4.82(3.09 ; 219.63)$ & $2.74(0.25 ; 3.84)$ & $0.38(0.04 ; 4.00)$ \\
\hline GSK-3 $\beta$ & $0.65(0.02 ; 1.65)$ & $30.62(12.49 ; 40.62)^{*}$ & $11.92(0.90 ; 23.35)$ & $4.00(3.63 ; 6.06)$ \\
\hline mTOR & $0.26(0.01 ; 1.00)$ & $42.72(12.42 ; 361.00)^{*}$ & $4.10(2.00 ; 79.00)$ & $2.30(0.50 ; 2.39)$ \\
\hline 70s 6 киназа & $0.65(0.25 ; 4.00)$ & $66.06\left(1.14 ; 141.26^{*}\right)$ & $1.17(0.75 ; 24.55)$ & $0.38(0.27 ; 2.00)$ \\
\hline 4EBP1 & $0.22(0.00 ; 0.74)$ & $0.05(0.02 ; 18.45)$ & $2.57(2.56 ; 3.80)$ & $2.00(0.00 ; 3.32)$ \\
\hline PTEN & $0.63(0.24 ; 4.00)$ & $31.19(12.32 ; 54.95)$ & $1.16(0.15 ; 1.30)$ & $0.76(0.02 ; 2.00)$ \\
\hline \multicolumn{5}{|c|}{ Transcription and growth factors } \\
\hline NFкBp65 & $5.16(0.50 ; 51.20)$ & $54.59(27.58 ; 95.19)^{*}$ & $1.16(0.13 ; 7.16)$ & $51.20(1.76 ; 69.66)$ \\
\hline $\mathrm{NF} \kappa \mathrm{Bp} 50$ & $6.96(0.50 ; 32.00)$ & $93.09(56.28 ; 120.93)^{*}$ & $16.00(1.22 ; 150.15)$ & $0.49(0.38 ; 8.57)$ \\
\hline VEGFR2 & $0.12(0.06 ; 0.76)$ & $40.52(4.03 ; 92.82)$ & $7.26(0.23 ; 68.21)$ & $0.76(0.10 ; 6.06)$ \\
\hline VEGF & $0.36(0.13 ; 1.00)$ & $86.61(0.98 ; 189.12)^{*}$ & $0.82(0.03 ; 21.00)$ & $6.06(1.69 ; 12.13)$ \\
\hline CA9 & $1.56(0.19 ; 4.00)$ & $17.20(1.49 ; 46.98)$ & $0.56(0.08 ; 86.83)$ & $0.96(0.19 ; 8.57)$ \\
\hline HIF-2 & $0.91(0.25 ; 1.27)$ & $10.48(1.32 ; 82.87)^{*}$ & $1.54(1.50 ; 27.62)$ & $0.76(0.09 ; 3.03)$ \\
\hline HIF-1 & $0.50(0.25 ; 16.62)$ & $10.70(5.35 ; 246.83)$ & $13.72(7.28 ; 46.44)$ & $0.50(0.12 ; 6.06)^{*}$ \\
\hline VHL & $0.81(0.27 ; 54.00)$ & $36.85(12.3 ; 301.95)^{*}$ & $3.81(1.70 ; 34.17)$ & $0.09(0.01 ; 0.12)^{* *}$ \\
\hline \multicolumn{5}{|l|}{ Hormone reception } \\
\hline TRIM16 & $0.47(0.42 ; 1.20)$ & $0.05(0.00 ; 35.13)$ & $7.63(4.55 ; 27.52)$ & $0.18(0.02 ; 6.80)^{*}$ \\
\hline $\operatorname{Brn} 3 \alpha$ & $0.22(0.04 ; 0.65)$ & $54.59(13.92 ; 136.67)$ & $3.06(1.23 ; 99.22)$ & $8.00(0.38 ; 11.59)$ \\
\hline $\mathrm{AR}$ & $0.22(0.01 ; 0.89)$ & $59.43(5.75 ; 364.26)$ & $1.44(0.57 ; 38.37)$ & $0.19(0.01 ; 2.00)$ \\
\hline $\mathrm{ER} \alpha$ & $1.22(0.44 ; 1.36)$ & $24.95(15.36 ; 80.75)$ & $8.00(1.53 ; 15.94)$ & $1.00(0.03 ; 1.52)^{* *}$ \\
\hline $\mathrm{ER} \beta$ & $0.84(0.42 ; 1.20)$ & $11.68(3.89 ; 35.13)$ & $1.71(0.52 ; 29.70)$ & $0.76(0.09 ; 0.78)$ \\
\hline
\end{tabular}


Table 4. BRAF-V600E Status in primary Cancers and Metastases in PTC

\begin{tabular}{lcc}
\hline BRAF-V600E status in primary tumor & BRAF-V600E status in metastasis & $\begin{array}{c}\text { Concordance of } B R A F-\mathrm{V} 600 \mathrm{E} \\
\text { tumor status and metastases }\end{array}$ \\
\hline 8 patients - positive in BRAF-V600E - 40\% & $\begin{array}{c}\text { 2 patients - positive in BRAF-V600E - 10\% } \\
\text { 6 patients - negative in BRAF-V600E - 30\% }\end{array}$ & $10 \%$ \\
12 patients - negative in BRAF-V600E - 60\% & $\begin{array}{l}\text { 4 patients - positive in BRAF-V600E 20\% } \\
\text { 8 patients - negative in BRAF-V600E } 40 \%\end{array}$ & $40 \%$ \\
\hline
\end{tabular}

It should be noted the molecular mechanisms of cancer spreading, metastasis formation, and LNMs affection in PTC are not studied yet. The single data evidence the $B R A F-\mathrm{V} 600 \mathrm{E}$ point mutation status does not affect the likelihood of regional lymph node involvement (Kurtulmus et al., 2016; Gawin et al., 2019). In turn, it is known the fact the $B R A F-\mathrm{V} 600 \mathrm{E}$ mutation protective effect. A decrease in the lung damage in PTC, despite the presence of unfavorable clinical parameters that determine a high risk of developing metastases in the lungs (larger tumor size and the presence of metastatic foci (more than $0,9 \mathrm{~cm}$ ) and surgical treatment over a year) was found (Lu et al., 2015).

The hormone receptors and transcription factors play a significant role in PTC progression (Stanley et al., 2012; Spirina et al., 2019). An increase in AR, ER $\beta$ mRNA level in the PTCs was revealed against the background of an ER $\alpha$ and ER $\beta$ expression imbalance (Spirina et al., 2018). However, no studies have been carried out in the LNMs. Simultaneously, the decrease in TRIM16 expression and $\mathrm{ER} \alpha$ detected in metastases with a positive $B R A F-\mathrm{V} 600 \mathrm{E}$ status. It probably, confirms the previously identified data regarding protection against lung metastases development in PTC (Walts et al., 2014).

The $B R A F$ positive status in primary tumors is an unfavorable prognostic factor related to predicting the effect of the targeted therapy and radiotherapy (Califano et al, 2018). It is known the $B R A F-\mathrm{V} 600 \mathrm{E}$ mutation in LNM may not be related to the invasive characteristics of PTCs (Vuong et al., 2017). As a result of the study, the significance of the concordance in the $B R A F$ status was revealed. Both $B R A F$ positive and negative status in

Table 5. Molecular Markers Expression in Primary Tumor and Metastases Depending on the Coincidence of $B R A F$-V600E Status in the Primary Tumor and Metastatic Tissue

\begin{tabular}{|c|c|c|c|c|}
\hline \multirow{2}{*}{$\begin{array}{l}\text { Indicator. } \\
\text { Relative Unit }\end{array}$} & \multicolumn{2}{|c|}{ Primary tumor } & \multicolumn{2}{|c|}{ Metastases } \\
\hline & $\begin{array}{c}\text { Primary tumor and metastasis } \\
\text { have the same status } \\
B R A F-\mathrm{V} 600 \mathrm{E}\end{array}$ & $\begin{array}{c}\text { Primary tumor and metastasis } \\
\text { have heterogenous } \\
B R A F-\mathrm{V} 600 \mathrm{E} \text { status }\end{array}$ & $\begin{array}{c}\text { Primary tumor and } \\
\text { metastasis have the same } \\
\text { status } B R A F-\mathrm{V} 600 \mathrm{E}\end{array}$ & $\begin{array}{c}\text { Primary tumor and } \\
\text { metastasis have heterogenous } \\
B R A F-\mathrm{V} 600 \mathrm{E} \text { status }\end{array}$ \\
\hline \multicolumn{5}{|c|}{ AKT / mTOR signaling pathway components } \\
\hline PDK & $2.24(0.60 ; 3.52)$ & $1.52(1.00 ; 284.21)$ & $1.77(0.01 ; 2.02)$ & $1.52(1.00 ; 115.00)$ \\
\hline $\mathrm{AKT}$ & $1.00(0.06 ; 1.43)$ & $1.00(0.38 ; 280.03)$ & $0.78(0.68 ; 1.02)$ & $0.54(0.38 ; 273.00)$ \\
\hline c-RAF & $6.24(1.41 ; 64.00)$ & $0.38(0.25 ; 433.03)$ & $0.25(0.05 ; 2.74)$ & $4.00(0.38 ; 33.700)^{* *}$ \\
\hline GSK-3 $\beta$ & $0.80(0.02 ; 1.65)$ & $0.50(0.39 ; 6.06)$ & $3.63(0.90 ; 11.92)$ & $6.06(4.00 ; 237.00)$ \\
\hline mTOR & $0.07(0.01 ; 0.46)$ & $2.30(1.00 ; 653.00)^{*}$ & $2.39(2.00 ; 4.10)$ & $2.30(0.50 ; 79.00)$ \\
\hline 70s 6 киназа & $0.92(0.82 ; 4.00)$ & $0.38(0.25 ; 151.86)$ & $0.75(0.27 ; 1.17)$ & $2.00(0.38 ; 592.00)$ \\
\hline 4EBP1 & $0.06(0.00 ; 0.74)$ & $0.19(0.01 ; 0.25)$ & $2.57(2.56 ; 3.32)$ & $2.00(0.00 ; 3.80)$ \\
\hline PTEN & $4.00(0.24 ; 6.78)$ & $0.76(0.50 ; 61.91)$ & $0.15(0.02 ; 1.16)$ & $2.00(0.76 ; 642.00)^{* *}$ \\
\hline \multicolumn{5}{|c|}{ Transcription and growth factors } \\
\hline NFkBp65 & $0.76(0.50 ; 9.56)$ & $51.20(44.80 ; 99.60)^{*}$ & $1.16(0.13 ; 1.76)$ & $69.66(51.2 ; 475.00)^{* *}$ \\
\hline NFkBp50 & $23.24(10.21 ; 32.00)$ & $0.50(0.38 ; 96.86)$ & $1.22(0.49 ; 16.00)$ & $8.57(0.38 ; 520.00)$ \\
\hline VEGFR2 & $0.12(0.06 ; 0.13)$ & $0.76(0.01 ; 112.64)$ & $0.23(0.13 ; 7.26)$ & $6.06(0.76 ; 481.00)$ \\
\hline VEGF & $0.34(0.13 ; 0.38)$ & $1.00(0.00 ; 12.13)$ & $0.82(0.03 ; 1.96)$ & $12.13(6.06 ; 21.00)^{* *}$ \\
\hline CAIX & $1.34(0.50 ; 2.62)$ & $1.65(0.19 ; 4.00)$ & $0.56(0.08 ; 0.96)$ & $8.57(0.19 ; 211.00)$ \\
\hline HIF-2 & $0.83(0.25 ; 1.27)$ & $1.00(0.43 ; 3.03)$ & $1.50(0.13 ; 1.54)$ & $3.03(0.76 ; 108.00)$ \\
\hline HIF-1 & $5.35(0.25 ; 16.62)$ & $1.00(0.50 ; 246.83)$ & $7.28(0.13 ; 13.72)$ & $6.06(0.50 ; 481.00)$ \\
\hline VHL & $2.68(0.52 ; 79.25)$ & $150.32(32.80 ; 225.9)^{*}$ & $1.70(0.72 ; 3.81)$ & $62.76(32.5 ; 100.5)^{* *}$ \\
\hline \multicolumn{5}{|c|}{ Hormone reception } \\
\hline TRIM16 & $0.07(0.00 ; 1.40)$ & $0.18(0.09 ; 1.73)$ & $4.55(0.26 ; 7.63)$ & $6.80(0.18 ; 104.00)$ \\
\hline $\operatorname{Brn} 3 \alpha$ & $0.65(0.04 ; 1.54)$ & $0.38(0.22 ; 21.59)$ & $3.06(1.23 ; 11.59)$ & $8.00(0.38 ; 406.00)$ \\
\hline $\mathrm{AR}$ & $0.89(0.01 ; 2.16)$ & $0.25(0.19 ; 621.15)$ & $0.57(0.02 ; 1.44)$ & $2.00(0.19 ; 302.00)$ \\
\hline $\mathrm{ER} \alpha$ & $1.02(0.44 ; 1.36)$ & $1.52(1.32 ; 31.80)^{*}$ & $1.53(1.07 ; 8.00)$ & $1.52(1.00 ; 16.00)$ \\
\hline $\mathrm{ER} \beta$ & $1.00(0.42 ; 1.40)$ & $1.00(0.76 ; 6.70)$ & $0.52(0.10 ; 1.71)$ & $0.78(0.76 ; 124.00)$ \\
\hline
\end{tabular}

*, the significance of the differences in markers in the tumor tissue; where the status of $B R A F$-V600E is identical in the tumor and metastases compared to non-concordant tissues, $\mathrm{p}<0.05 ; * *$, the significance of the differences in markers in the tissue of metastases, where the status of $B R A F-\mathrm{V} 600 \mathrm{E}$ is identical in the tumor and metastases in comparison with non-concordant tissues, $\mathrm{p}<0.05$; 
primary tumors and LNMs led to the low mRNA levels of studied indicators. Simultaneously, in the concordance absence, growth in molecular markers was observed, accompanied by oncogenesis activation. Mutation loss in metastases was found to be a sign of aggressive cancer cell behavior. The revealed fact explains the fact of a PTCs favorable prognosis in most patients, which is associated with the presence of concordance in the $B R A F-\mathrm{V} 600 \mathrm{E}$ status in the primary tumor and LNMs in more than $90 \%$ of patients (Sohn et al., 2016).

In conclusion, the heterogeneity in the primary tissue's expression profile and the metastases was noted. The BRAF-V600E mutation can affect the molecular characteristics both in the primary cancers and LNMs. In tumor tissues, the intensity of oncogenesis is higher in comparison with metastatic ones. In patients with the mutation, an increase in the expression of the studied marker in the primary tumor was shown, in contrast to the metastases, where the molecular factors' expression was reduced. The molecular factors variability in the primary tumor and LNMs determines the tumor's progression. The significance of the HIF, VHL expression, and the $B R A F-V 600 \mathrm{E}$ point mutation in the PTC's development was noted. The discrepancy between the mutant status in the primary tumor and metastatic tissues may be an essential factor associated with the cancer spreading.

\section{Author Contribution Statement}

Liudmila Spirina - manuscript drafting; Irina Kovaleva - review-analysis; Svetlana Chizhevskaya study concept.

\section{Aknowledgements}

\section{Students thesis approval}

Scientific body or any part of it was no approved as a student thesis

\section{Ethical committee}

The Ethical Committee of Cancer Research Institute of Tomsk National Research Medical Center approved the research.

\section{Conflict of interests}

None.

\section{References}

Albini A, Tosetti F, Li VW, Noonan DM, Li WW (2012). Cancer prevention by targeting angiogenesis. Nat Rev Clin Oncol, 9, 498-09.

Bhagirath D, Yang TL, Tabatabai ZL, et al (2019). BRN4 is a novel driver of neuroendocrine differentiation in castrationresistant prostate cancer and is selectively released in extracellular vesicles with BRN2. Clin Cancer Res, 25, 6532-45.

Califano I, Deutsch S, Löwenstein A, Cabezón C, Pitoia F (2018). Outcomes of patients with bone metastases from differentiated thyroid cancer. Arch Endocrinol Metab, 62, 14-20.

Chen P, Ouyang W, Feng H, et al (2018). The association of

\section{The BRAF-V600E Mutation and Papillary Thyroid Cancer}

the $B R A F$ V600E mutation with a protective factor for lung metastases in papillary thyroid cancer. $J$ Nucl Med, 59, 1307.

Chen P, Pan L, Huang W, et al (2020). BRAF V600E and lymph node metastases in papillary thyroid cancer. Endocr Connect, 9, 999-8.

Dagogo-Jack I, Shaw AT (2018). Tumour heterogeneity and resistance to cancer therapies. Nat Rev Clin Oncol, 15, 81-94.

Gawin M, Kurczyk A, Stobiecka E, et al (2019). Molecular heterogeneity of papillary thyroid cancer: Comparison of Primary Tumors and Synchronous Metastases in Regional Lymph Nodes by Mass Spectrometry Imaging. Endocr Pathol, 30, 250-61.

Ge J, Wang J, Wang H, et al (2020). The BRAF V600E mutation is a predictor of the effect of radioiodine therapy in papillary thyroid cancer. J Cancer, 11, 932-9.

Halon A, Nowak-Markwitz E, Maciejczyk A, et al (2011). Loss of estrogen receptor beta expression correlates with shorter overall survival and lack of clinical response to chemotherapy in ovarian cancer patients. Anticancer Res, 31, 711-8.

Jena KK, Mehto S, Kolapalli SP, et al (2019). TRIM16 governs the biogenesis and disposal of stress-induced protein aggregates to evade cytotoxicity: implication for neurodegeneration and cancer. Autophagy, 15, 924-6.

Kurtulmus N, Ertas B, Saglican Y, et al (2016). BRAFV600E Mutation: Has It a Role in Cervical Lymph Node Metastasis of Papillary Thyroid Cancer. Eur Thyroid J, 5, 195-0.

Lodewijk L, van Diest P, van der Groep P, et al (2017). Expression of HIF-1 $\alpha$ in medullary thyroid cancer identifies a subgroup with poor prognosis. Oncotarget, 8, 28650-9.

$\mathrm{Lu} \mathrm{J}$, Gao J, Zhang J, et al (2015). Association between BRAF V600E mutation and regional lymph node metastasis in papillary thyroid carcinoma. Int J Clin Exp Pathol, 8, 793-9.

Magri F, Capelli V, Rotondi M, et al (2012). Expression of estrogen and androgen receptors in differentiated thyroid cancer: an additional criterion to assess the patient's risk. Endocr Relat Cancer, 19, 463-71.

Melo M, Gaspar da Rocha A, Batista R, et al (2017). TERT, BRAF, and NRAS in Primary Thyroid Cancer and Metastatic Disease. J Clin Endocrinol Metab, 102, 1898-907.

Parameswaran R, Shulin HJ, Min EN, Tan WB, Yuan NK (2017). Patterns of metastasis in follicular thyroid carcinoma and the difference between early and delayed presentation. Ann $R$ Coll Surg Engl, 99, 151-4.

Sadow PM, Heinrich MC, Corless CL, Fletcher JA, Nosé V (2010). Absence of BRAF, NRAS, KRAS, HRAS mutations, and RET/PTC gene rearrangements distinguishes dominant nodules in Hashimoto thyroiditis from papillary thyroid carcinomas. Endocr Pathol, 21, 73-9.

Shen X, Zhu G, Liu R, et al (2018). Patient age-associated mortality risk is differentiated by BRAF V600E status in papillary thyroid cancer. J Clin Oncol, 36, 438-45.

Spirina LV, Chizhevskaya SY, Kondakova IV (2018). Expression of transcription and growth factors and the AKT/m-TOR signaling pathway components in papillary thyroid cancer. Problems Endocrinol, 64, 208-15.

Spirina LV, Chizhevskaya SY, Kondakova IV, Choinzonov EL (2018). Reception of sex steroid hormones in thyroid papillary cancer tissue and relationship with expression and content of transcription factors Brn-3 $\alpha$ and TRIM16. Bull Exp Biol Med, 166, 237-40.

Spirina IV, Chigevskaya SY, Kondakova IV, Choynzonov EL (2019). The relationship of the BRAF-V600E mutation with the expression of transcriptional, growth factors, components of the AKT / m-TOR signaling pathway in the tissue of papillary thyroid cancer. Vopr Onkol, 65, 608-13.

Spirina LV, Yunusova NV, Kondakova IV, Tarasenko NV (2019). 
Transcription factors Brn-3 $\alpha$ and TRIM16 in cancers, association with hormone reception. Heliyon, 5, e02090.

Spirina LV, Malysheva KS, Chizhevskaya SU, Kondakova IV, Kovaleva IV (2020). Expression of factors activated by hypoxia, growth factor VEGF, its receptor, carbohydrase IX in tissue in papillary cancers and metastases. Molekulyarnaya Meditsina, 18, 57-63.

Sohn SY, Park WY, Shin HT, et al (2016). Highly concordant key genetic alterations in primary tumors and matched distant metastases in differentiated thyroid cancer. Thyroid, 26, 672-82.

Stanojevic B, Saenko V, Todorovic L, et al (2014). Low VHL mRNA expression is associated with more aggressive tumor features of papillary thyroid carcinoma. PLoS One, 9, e114511.

Stanley JA, Aruldhas MM, Chandrasekaran M, et al (2012). Androgen receptor expression in human thyroid cancer tissues: a potential mechanism underlying the gender bias in the incidence of thyroid cancers. J Steroid Biochem Mol Biol, 130, 105-24.

Tan H, Qi J, Chu G, Liu Z (2017). Tripartite motif 16 inhibits the migration and invasion in ovarian cancer cells. Oncol Res, 25, 551-8.

Todorović L, Stanojević B, Mandušić V, et al (2018). Expression of VHL tumor suppressor mRNA and miR-92a in papillary thyroid carcinoma and their correlation with clinical and pathological parameters. Med Oncol, 35, 17.

Vuong HG, Altibi AM, Duong UN, et al (2017). Role of molecular markers to predict distant metastasis in papillary thyroid carcinoma: Promising value of TERT promoter mutations and insignificant role of BRAF mutations-a metaanalysis. Tumour Biol, 39, 1010428317713913.

Walts AE, Pao A, Sacks W, Bose S (2014). BRAF genetic heterogeneity in papillary thyroid carcinoma and its metastasis. Hum Pathol, 45, 935-41.

Xing M, Alzahrani AS, Carson KA, et al (2013). Association between BRAF V600E mutation and mortality in patients with papillary thyroid cancer. JAMA, 309, 1493-501.

\section{(c) (i) \&}

This work is licensed under a Creative Commons AttributionNon Commercial 4.0 International License. 